\title{
多発奇形を合併した混合性難聴例
}

\author{
近藤 千雅・北原 糺*・森鼻 哲生・奥村 新一
}

\section{A Case of Mixed Hearing Loss Accompanied with Multiple Congenital Malformations}

\author{
Kazumasa Kondoh, Tetsuo Morihana and Shin-ichi Okumura \\ (Osaka Rosai Hospital) \\ Tadashi Kitahara \\ (Osaka University)
}

\begin{abstract}
We report a case of mixed hearing loss accompanied by multiple malformations in a 5 -year-old male. His mother first suspected that her child had reduced hearing, when he was 5-years and 2-months-old. Nine months later, she brought her son for a hearing test. Audiometry showed a mild low frequency mixed hearing loss bilaterally.

As a past history, he had a ventricular septal defect and hypoplasia of the bilateral big toes. Family history was noncontributory; there was no history of a similar illness in other family members or relatives.

We peformed exploratory surgery. The round window niche was obscure and the circumferential bony wall of the cochlea was thin. So we abandoned the surgical attempt at hearing improvement.

In the embryo, the differentiation period of each organ varies. Accordingly, we considered that some teratogenic factor may have had an effect on the embryo in the $5 \sim 6$ th weeks of viviparity when the differentiation period of the malformed organs overlapped each other.
\end{abstract}

Key words : mixed hearing loss, multiple malformations, middle-internal ear, ventricular septal defect (VSD), big toe

はじめに

先天異常（congenital anomaly）は，出生時にみられる 形態的および機能的異常である.この形態的・機能的 異常は個人が社会生活を送る上で，多大な影響を及ぼ し，非常に深刻な問題となる．先天奇形 (congenital malformation） は先天異常のうち形態的な異常を指し，大 きくは外表奇形と内蔵奇形とに分けられ，この両者はし ばしば合併してみられることがある，今回われわれは， 全身の多発奇形に，中内耳奇形を合併した症例を経験し たので，若干の文献的考察を加えて報告する.

\section{症例}

症例 : 5 歳 11 力, 男児.

主訴：左難聴.

既往歴: 生来, 心室中隔欠損症（膜性部周囲欠損）, 両 側母趾末節欠損.

家族歴：近親者に難聴者なく,また患児の母親（32 歳） に飲酒・喫煙歷なく, 妊娠中の薬物使用やウイルス感染 の既往なし。

現病歴：周産期に異常を認めず，在胎 40 週正常分婏に て出生. 成長および精神発達にも異常を認めなかった. 5 


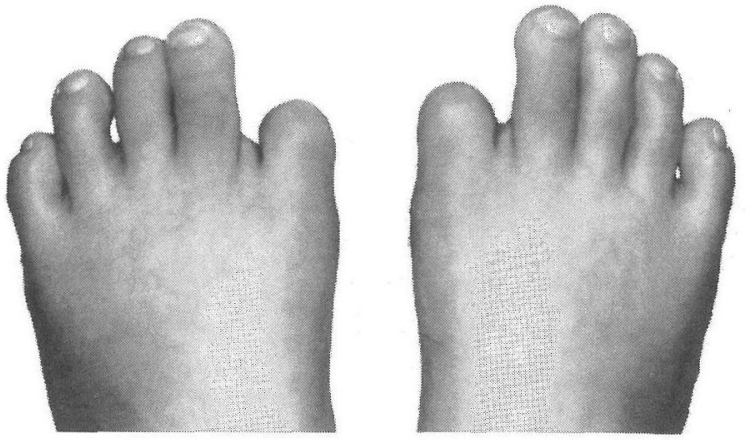

図 1 足の写真 両側母趾末節の欠損を認める.

歳 2カ月時，左からの問いかけに対して反応が鈍いこと に家人が気づき近医を受診したところ，聴力検査で左混 合性難聴を指摘され，原因精查および加療目的で当科に 紹介受診となった。

初診時所見：両側の耳介，外耳道，鼓膜には異常を認 めなかった。身長 $113 \mathrm{~cm}$ ，体重 $20 \mathrm{~kg}$ で，発育成長およ び精神発達は正常であったが，両側母趾末節欠損（図 1） を認めた。

検査所見: 標準純音聴力検查は初診時以降 3 回施行し, いずれも再現性を認めた。その結果，両側とも stiffness curve を示す低音障害型の混合性難聴を呈した（図 2)。

MANU.

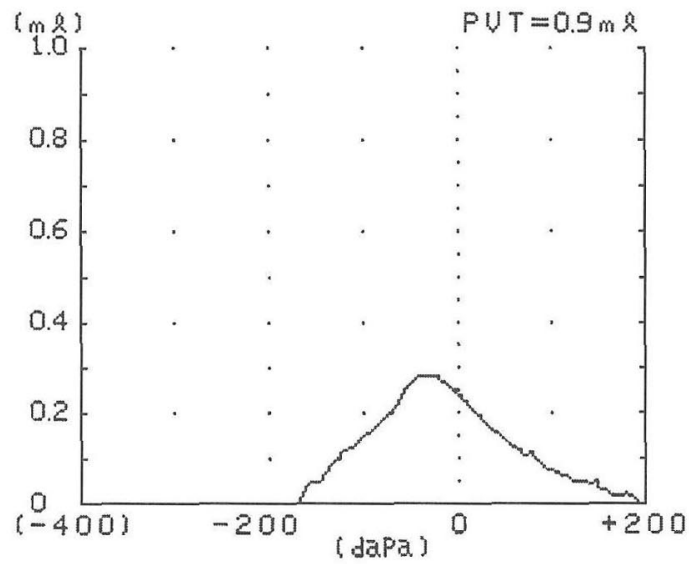

右

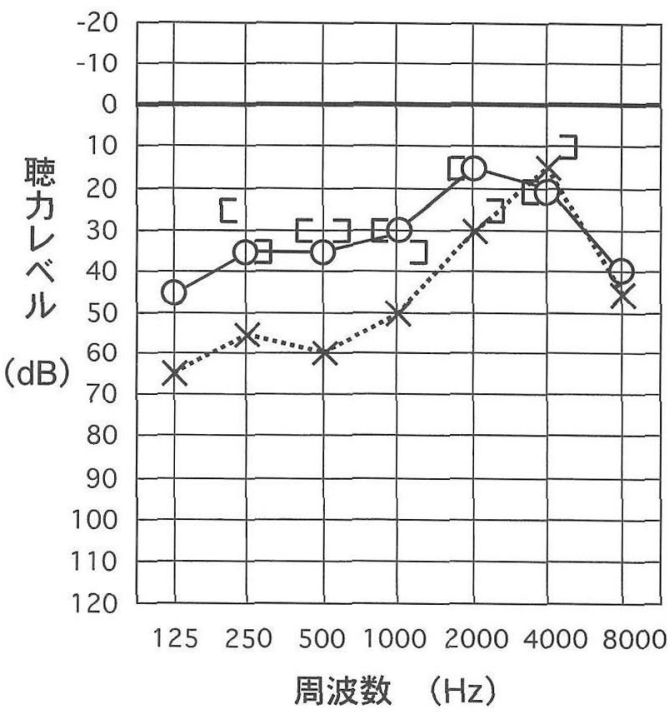

図 2 標準純音聴力検查

両側 stiffness curve を示す低音障害型の混合性難聴。

ティンパノグラムでは両側 As 型を示した（図 3).アブ ミ骨筋反射は両側とも消失していた。側頭骨高分解能 CT （HRCT）上，両側とも前庭空周囲に限局した蛤牛の形成 不全を認めたが，螖牛軸回転は正常に描出されている。 ツチ骨，キヌタ骨は正常位置に描出されており，またア ブミ骨も形成不全の前庭空部に位置してほぼ正常に描出 されている。
MANU.

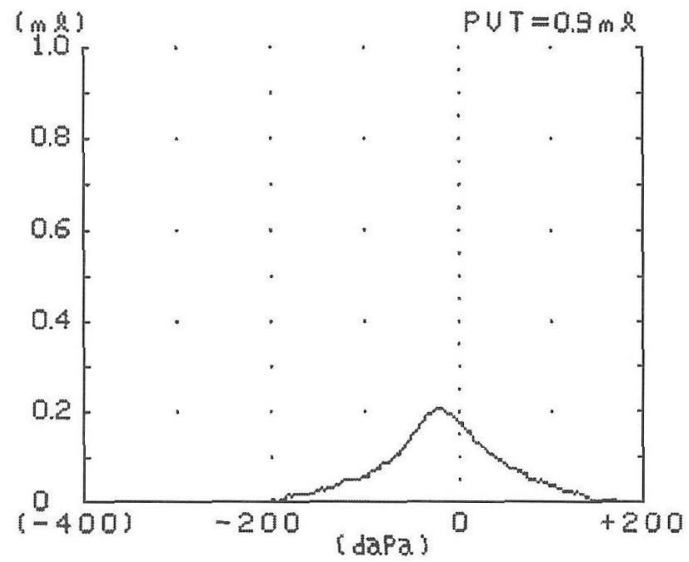

左

図 3 ティンパノグラム 両側 As 型を示している。 

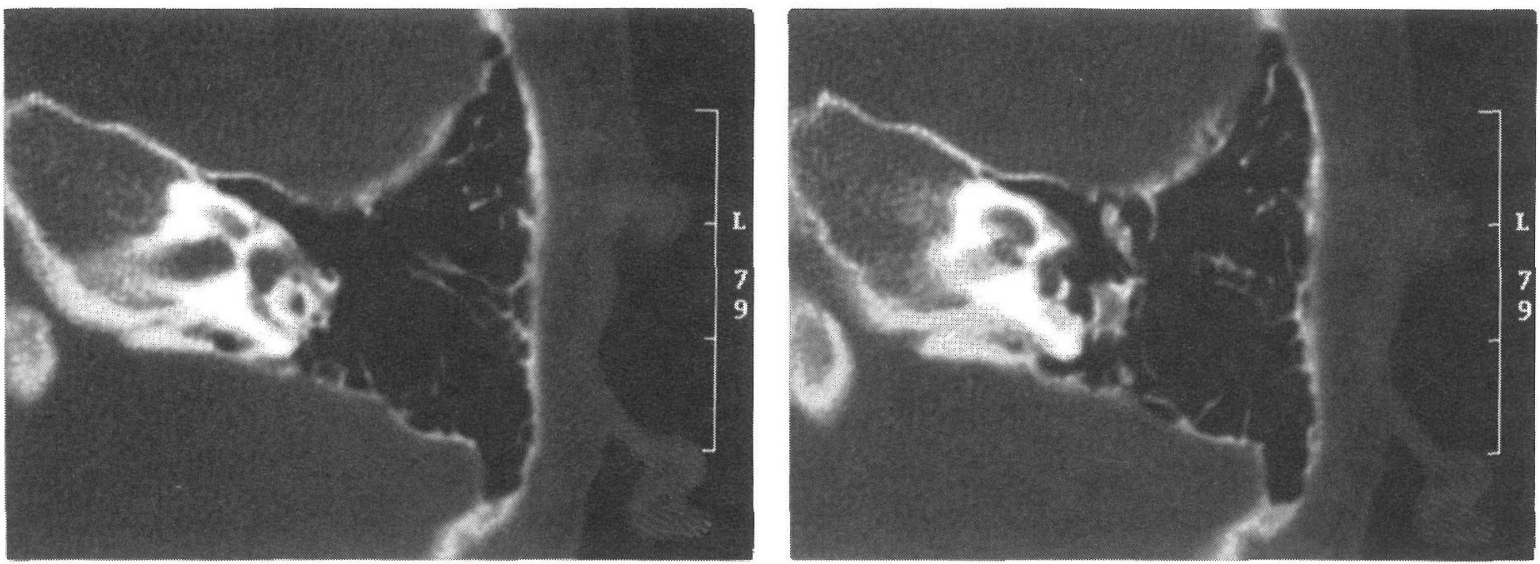

図 4 側頭骨高分解能 CT $(\mathrm{HRCT})$

前庭愍周囲に蝸牛骨壁の形成不全を認めるが，耳小骨，蝸牛軸回転，内耳道，半規管は正常に描出されている.

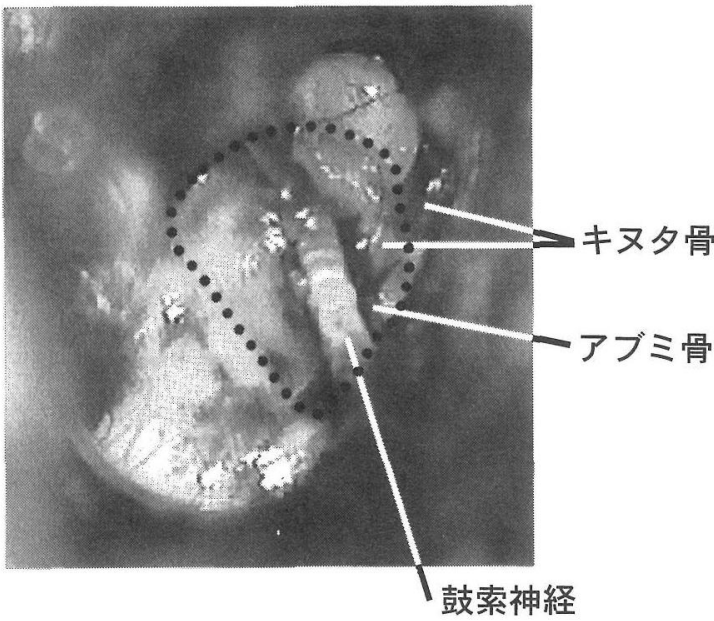

図 5 手術所見(左試験的鼓室開放術)

前庭空付近の岬角（螖牛骨壁）の菲薄化により，内耳が 青黒く透見される (点線枠内).

乳突蜂巣の発育は良好で錐体部も高度に含気化されて いる。内耳道，半規管は正常であった（図 4)。血液生化 学検査では，Ca，P，ALP を含め，異常值は認めなかっ た。また，他院小児科で施行した染色体検查でも異常は 認められなかった。

手術所見：平成 12 年 9 月 18 日，両親の同意のもと全 身麻酔下に聴力閾值の高い左耳の試験的鼓室開放術を施 行した。耳後部切開法にて鼓室を開放したところ，キヌ タ骨長脚先端および豆状突起は形成不全があり細小化し ていたが、キヌタ・アブミ骨連鎖は存在していた。また，
最も特徴的な所見として, 前庭空周团の䛅角 (螖牛骨壁) 形成不全を認め，菲薄化した骨壁を通して前庭腔内が青 黒く透見された。アブミ骨の形状は上部構造は正常で あったが，前庭梥の輪状䩲带は欠損し，底板と骨性癒合 していたため，底板の輪郭は不明瞭であった。このため， アブミ骨底板が固着し，可動性が障害されていた。蝸牛 容周囲の岬角（螖牛骨壁）形成は正常であった（図 5).

アブミ骨底板とその周囲の岬角の菲薄化所見や先天性 アブミ骨固着に対する前庭空開公の際の perilymphatic gusherを危惧し，アブミ骨手術は施行せず，そのまま閉 創し手術を終了した。術後聴力は術前と同様であった。

\section{考 察}

多発奇形を呈する症例を扱ら場合，正確に異常を把握 し煩雑な奇形の組み合わせを系統的に診療するために一 般的には奇形を複数のカテゴリーに分類して解析が進め られる。多発奇形のカテゴリー化は，機能面で重大な障 害の原因となる大奇形と日常生活に支障をきたさない程 度の軽微な形態異常である小奇形の有無によって,「偶発 的な奇形の組み合わせ」・奇形の併存（奇形の組み合わ せは偶然の確率以上であるが，連鎖や症候群には属さな い)」・「奇形の連鎖（原発の構造異常に続発した奇形）」・ 「奇形症候群（染色体異常, 遺伝子異常による既知の症候 群，原因不明の奇形症候群，既知の胎芽病）」の大きく 4 つに分類される122)。奇形症候群とは，书そらく同一の原 因によると考えられる多系統に及命奇形で，一つの原発 形態発生異常では説明できないものである。 
松井 ${ }^{3 ）}$ の診断手順に沿って自験例を分析すると，大奇 形として中内耳奇形と心奇形，小奇形として母趾低形成 の存在が挙げられる. 小奇形は, 染色体異常や奇形症候 群の診断のための index（指標）として非常に有用であ る. 前述の自験例のような中内耳および心臟の大奇形に 母趾低形成という小奇形が合併する組み合わせは，過去 に報告がないためカテゴリーとして「奇形の併存 (association)」や「既知の奇形症候群」は否定される. ま た，中内耳と心藏，母趾の奇形は，お互いが先行するも のと続発するものという関係ではないため,「奇形の連 鎖」も該当しない.したがって，消去法的結論として自 験例の奇形のカテゴリーとしては,「偶発的な奇形の組み 合わせ」あるいは，「原因不明の奇形症候群」に分類され ると考えられる．ただし，今回確認された奇形の項目は 3 つあり，実際にすべてが偶発的に同一個体に発生する 確率はきわめて低率である.

形態発生異常の原因としては，遺伝要因によるものと 環境要因によるものがある。一般に生まれてきた新生児 のらち約 5\%は何らかの先天異常がみられ，そのらち 20 \%は遺伝子病, $6 \%$ は染色体異常, 5 〜 10\%は主として環 境要因（胎内環境）によるものであるが，残りの 65 〜 $70 \%$ は原因不明である ${ }^{4)}$. 自験例では, 母趾, 中内耳と もに両側に同様の奇形が発現していることや，近親者に 同様の所見・症状を認める者がいないこと，また染色体 異常もないことから，偶発的事象ではなく単因子あるい は多因子的要素が一定期間, 胎児に作用したことによる 必然的発症の可能性が高い。しかしながら受胎中の母親 にウイルス感染や飲酒, 薬物使用の経歴がないことなど, はっきりと同定できる原因は定かではない.

受精 8 週目までの胚子期（胎芽期）に催奇形因子の影 響を受けると主に形態的な異常を生じ，受精後 9 週から 出生するまでの胎児期に影響を受けると，主に機能的欠 損を生じる，さらに，各臓器・器官においては，最も催 奇形因子による影響を受けやすい臨界期 (critical period) といわれる時期がある。

心臟血管系の発生 5) において最も感受性の高い時期は 胎生第 3 週から第 6 週にかけてで，第 5 週に入り左右の 心室間に筋性中隔の形成が開始され，最終的に残存する 室間孔の右端が閉じて膜性中隔となる.

指趾の発生 $\left.{ }^{6}\right)$ においては，第 5 週の間に手足の原基が はっきりしてきて肢板となり, 続いて第 6 週になると将 来の各指の位置に対応して指放線と呼ばれる 5 本の棒状
構造をとる細胞集団を形成し，そのなかに将来骨になる 軟骨が形成される．この第 $5 \sim 6$ 週前後の期間が指趾の 臨界期に相当する。

耳に関して7 ${ }^{7}$ は，外胚葉性の上皮をもつ外耳，第 1 鰓 囊由来の内胚葉上皮と鰓弓の中胚葉加主に発生する中 耳, および表層外胚葉と間葉から形成される内耳とそれ ぞれ発生起源が異なり，それに応じて臨界期も第 $4 \sim 12$ 週頃と比較的長期にわたる. 内耳は, 第 3 週の終わりに 耳板（耳プラコード）が耳の 3 つの区分のなかで最も早 く出現する．耳板は第 4 週には耳胞をつくり，やがて卵 形囊，球形囊，半規管，螖牛へと分化する。 さらに第 8 週には前庭階, 鼓室階が形成される. 耳小骨原基が最初 に認められるのは第4週で, 第 1 鰓弓より発生した Meckel 軟骨からッチ骨，キヌタ骨原基が，第 2 鰓弓より発生し た Reichert 軟骨からアブミ骨原基が形成される. 第 7 週 には各原基は形態が整い，軟骨化が始まるとともにアブ ミ骨原基が将来の前庭空の部分で螖牛原基の耳胞に接着 し，接着部の細胞群がアブミ骨底の前庭空側の一部と輪 状勒帯に分化する。

以上より, 自験例において生じた心臟, 指趾, 中内耳 の奇形部位の分化時期および各臟器・器官の臨界期を照 らし合わせて考慮すると, 胎生 $5 \sim 6$ 週頃に各臟器 - 器 官の分化時期や臨界期が重なっていることから，少なく ともこの時期に催奇形因子が胎児に対して作用を及ぼし ていた可能性が高いと考えられた。

耳の奇形と先天性心疾患との関連については以前より 指摘されており ${ }^{8)}$ 10)，加ては Cardioauditory 症候群と 呼ばれたことがある，先天性心疾患を有した小児の側頭 骨病理組織に関する報告9)11) では，間葉組織の遺残，高 位頸静脈球, キヌタ骨の拡大などの中耳の異常と短蝸牛, 外側 - 後半規管の異常, 大きな前庭, 蝸牛水管の欠損な ぞの内耳の異常所見が認められたとしている。このよう な発生学的事実加察すると, 中・内耳の発生分化に影 響する因子は同時に心臓にも影響を及ぼしていたという 事実の強い裏づけ証拠となる.

近年の 2 次元高分解能 CT や 3 次元 $\mathrm{CT}, \mathrm{MRI}$ などの 画像技術の発達により, 耳小骨や内耳の細やかな異常が 比較的詳細に把握できるようになってきた。しかしなが ら，臨床現場での実際の使用には，まだ処理法や時間的 に制限があり，その得られる情報量にも限界がある。 た，耳小骨の固着の有無や程度も画像から判断すること は困難であり，実際の確定診断はやはり試験的鼓室開放 
術によると考えられる．中耳奇形は，手術により聴力の 改善が期待し得る症例が多く ${ }^{12)}$, 諸検査の結果をよく吟 味して聴力改善の余地があると判断した場合は，家族に 十分な説明をし同意を得た上で, 患児にとって局所処置 が可能となる頃に手術を計画することが望ましい.

\section{まとめ}

1）心奇形, 足指母趾末節欠損に中内耳奇形を合併した 1 症例を報告した。

2）試験的鼓室開放術を施行したが, 前庭空の形成不全 および前庭公部周囲蝸牛骨壁の菲薄化を認めたため, 聴 力改善手術は不可能であった。

3）心臓, 指趾および中内耳の発生において, 分化時期 が共通する胎生第 $5 \sim 6$ 週頃に胎児に催奇形因子が影響 を及ぼしていた可能性が示唆された。

なお，本論文の要旨は第 276 回日本耳鼻咽喉科学会大阪地方 連合会（平成 13 年 3 月, 大阪市）に执いて口演した。

\section{参考文献}

1) Thompson JS and Thompson MW : Genetics in Medicine. 6th edition (ed by Robert LN, Roderick RM and Huntington FW). Saunders, Philadelphia, 2002.

2) Smith DW : Classification, nomenclature, and naming of morphologic defects. J Pediatr $87: 162 \sim 163,1975$.

3）松井一郎：外耳.中耳奇形の遺伝学的背景. JOHNS $2: 13$ $\sim 27,1986$.

4) 福嶋義光：奇形・染色体異常. 新生児学（小川雄之亮, 多 田 裕, 中村 肇, 他編). $678 \sim 695$ 頁, メディカ出版, 大阪, 2000.

5) Fitzgerald $M$ : Circulatory organ. Human Embryology (ed by Fitzgerald M). pp $80 \sim 107$, Bailliere Tindall, London, 1994.

6) 渡辺好博: 手関節および手指. 標準整形外科学 第 7 版 (寺 山和雄, 辻 陽雄編). $360 \sim 369$ 頁, 医学書院, 東京, 1999 .

7) 中井義明：臨床解剖（外耳・中耳・内耳）。標準耳鼻咽喉 科・頭頸部外科学 第 3 版（鈴木淳一, 中井義明, 平野 実編). $197 \sim 198$ 頁, 医学書院, 東京, 1997.

8) Kelemen $G$ : Aural participation in congenital malformations of the organism. Acta Otolaryngol Suppl (Stockh) $321: 1 \sim 35$, 1974.

9) Egami T, Sando I and Myers EN : Temporal bone anomalies associated with congenital heart disease. Ann Otol Rhinol Laryngol $88: 72 \sim 78,1979$.

10）加我君孝, 都筑俊寛, 田中美鄉 : 内耳奇形症例の合併症の 種類について. Otol Jpn $1:$ 160, 1991.

11）小山 悟: 重度の内臓奇形を持つ新生児の側頭骨病理所見. 日耳鼻 $99: 1079 \sim 1084,1996$.

12）小島博己, 宮崎日出海, 田中康広, 他: 鼓膜所見正常な耳 小骨奇形 72 耳の検討. 日耳鼻 $101: 1373 \sim 1379,1998$.

原稿受付：平成 14 年 7 月 4 日 原稿採択 : 平成14年 8 月 21 日 別刷請求先 : 近藤千雅 于591-8025 堺市長曽根町1179-3 大阪労災病院耳鼻咽喉科 